\title{
COVID-19 and Its Repercussions on Oral Health: A Review
}

\author{
Laura-Cristina Rusu ${ }^{1}$ (D), Lavinia Cosmina Ardelean ${ }^{2, * \mathbb{D}}$, Codruta Victoria Tigmeanu ${ }^{2}$, Anamaria Matichescu ${ }^{3, *(\mathbb{D})}$, \\ Iulia Sauciur ${ }^{1}$ and Emanuel Adrian Bratu ${ }^{4}$
}

1 Department of Oral Pathology, Multidisciplinary Center for Research, Evaluation, Diagnosis and Therapies in Oral Medicine, "Victor Babeș" University of Medicine and Pharmacy Timisoara, 2 Eftimie Murgu Sq., 300041 Timisoara, Romania; laura.rusu@umft.ro (L.-C.R.); sauciuriulia@yahoo.com (I.S.)

2 Department of Technology of Materials and Devices in Dental Medicine, Multidisciplinary Center for Research, Evaluation, Diagnosis and Therapies in Oral Medicine, "Victor Babeș" University of Medicine and Pharmacy Timisoara, 2 Eftimie Murgu Sq., 300041 Timisoara, Romania; tigmeanu.codruta@umft.ro

3 Department of Preventive Dentistry, Community and Oral Health, Translational and Experimental Clinical Research Center in Oral Health, "Victor Babeș" University of Medicine and Pharmacy Timisoara, 2 Eftimie Murgu Sq., 300041 Timisoara, Romania

4 Department of Implant Supported Restorations, "Victor Babeș" University of Medicine and Pharmacy Timisoara, 2 Eftimie Murgu Sq., 300041 Timisoara, Romania; ebratu@umft.ro

* Correspondence: lavinia_ardelean@umft.ro (L.C.A.); matichescu.anamaria@umft.ro (A.M.)

Citation: Rusu, L.-C.; Ardelean, L.C.; Tigmeanu, C.V.; Matichescu, A.; Sauciur, I.; Bratu, E.A. COVID-19 and Its Repercussions on Oral Health: A Review. Medicina 2021, 57, 1189. https://doi.org/10.3390/ medicina57111189

Academic Editors: Cesare D'Amico and Pier Paolo Poli

Received: 6 October 2021

Accepted: 28 October 2021

Published: 1 November 2021

Publisher's Note: MDPI stays neutral with regard to jurisdictional claims in published maps and institutional affiliations.

Copyright: (c) 2021 by the authors. Licensee MDPI, Basel, Switzerland. This article is an open access article distributed under the terms and conditions of the Creative Commons Attribution (CC BY) license (https:/ / creativecommons.org/licenses/by/ $4.0 /)$.

\begin{abstract}
In 2019, a new type of coronavirus, SARS-CoV-2, the causing agent of COVID-19, was first detected in Wuhan, China. On 11 March 2020, the World Health Organization declared a pandemic. The manifestations of COVID-19 are mostly age-dependent and potentially more severe in cases with involved co-morbidities. The gravity of the symptoms depends on the clinical stage of the infection. The most common symptoms include runny nose and nasal congestion, anosmia, dysgeusia or hypogeusia, diarrhea, nausea/vomiting, respiratory distress, fatigue, ocular symptoms, diarrhea, vomiting, and abdominal pain. These systemic conditions are often accompanied by skin and mucosal lesions. Oral lesions reported in patients with COVID-19 include: herpex simplex, candidiasis, geographic tongue, aphthous-like ulcers, hemorrhagic ulcerations, necrotic ulcerations, white hairy tongue, reddish macules, erythematous surfaces, petechiae, and pustular enanthema. It is still unclear if these manifestations are a direct result of the viral infection, a consequence of systemic deterioration, or adverse reactions to treatments. Poor oral hygiene in hospitalized or quarantined COVID-19 patients should also be considered as an aggravating condition. This narrative review is focused on presenting the most relevant data from the literature regarding oral manifestations related to SARS-CoV-2, as well as the challenges faced by the dental system during this pandemic. A routine intraoral examination is recommended in COVID-19 patients, either suspected or confirmed, as, in certain cases, oral manifestations represent a sign of severe infection or even of a life-threatening condition. It is our belief that extensive knowledge of all possible manifestations, including oral lesions, in cases of COVID-19 is of great importance in the present uncertain context, including new, currently emerging viral variants with unknown future impact.
\end{abstract}

Keywords: COVID-19; SARS-CoV-2; pandemic; oral lesions; oral manifestations; periodontal disease; temporomandibular disorders; dental medicine

\section{The Essentials about CoVs}

Coronaviruses (CoVs) are members of the Coronaviridae family. These enveloped viruses possess a non-segmented, single-stranded, positive-sense RNA, with a unique replication strategy [1].

CoVs are known to affect different animal species and cause mild to severe respiratory infections in humans. In 2002 and 2012, two highly pathogenic coronaviruses of zoonotic origin, causing the severe acute respiratory coronavirus syndrome (SARS-CoV-1) and the Middle East respiratory coronavirus syndrome (MERS-CoV), respectively, affected humans, 
resulting in fatal respiratory diseases [2,3], and turning coronaviruses into a 21st century public health problem. The virus has been identified in various non-human hosts [4-7]. Extremely pathogenic CoVs belong to the genus Beta-coronavirus, group 2, which causes severe disease [8].

In 2019, a new type of coronavirus, SARS-CoV-2, a Beta-coronavirus causing the COVID-19 disease, was first detected in Wuhan, China [9]. SARS-CoV-2 is composed of 16 non-structural proteins with specific roles in replication [10]. COVID-19 has spread rapidly around the world and, on 11 March 2020, the World Health Organization declared it a pandemic [11].

The SARS-CoV-2 genome sequence shares $\sim 80 \%$ sequence identity with SARS-CoV- 1 and $\sim 50 \%$ with MERS-CoV [12]. The structural spike protein (S), which mediates SARS$\mathrm{CoV}^{\prime} \mathrm{s}$ entry into host cells, is highly variable in the case of SARS-CoV-2. Its receptor-binding domain enables direct contact with the cell receptor angiotensin-converting enzyme II (ACE2) $[5,13]$.

ACE2, and thus any cells that express ACE2, may be target cells and therefore susceptible to COVID-19 infection [12]. Zou et al. [14] explored the expression of the ACE2 receptor on different cells from human body tissues and classified the infectious risk potential. Lung, heart, esophagus, kidney, bladder, and ileum have been considered organs at risk [14]. A high ACE2 expression was found in the oral mucosa and the epithelial cells of the tongue [15]. After entering the cell, the virus delays the immune system response, allowing the infection to progress, and it becomes much harder to fight [16].

\section{Main Characteristics of COVID-19}

\subsection{General Characteristics}

The host's response represents an important factor in the disease process and tissue damage. In most cases of SARS-CoV-2 infection, the primary immune response leads to viral elimination. In certain patients, the secondary immune response may be exaggerated and lead to inflammation-induced lung damage, pneumonia, acute respiratory distress syndrome, respiratory failure, shock, organ failure, and possible death [17].

Severe COVID-19 is also characterized by hypercoagulopathy and neurological and/or gastrointestinal tract damage, the fatal outcome in severe cases being due to the macrophage activation syndrome, which causes a "cytokine storm" [18].

Age, acute cardiac injury, heart failure, skeletal muscle injury, and lymphopenia have been associated with mortality in COVID-19 cases $[19,20]$.

The most common symptoms (Figure 1) include fever, cough, runny nose and nasal congestion, anosmia, dysgeusia/hypogeusia, diarrhea, and nausea/vomiting [21,22]. Other clinical manifestations include: fatigue, ocular symptoms (conjunctival secretion), and arrhythmias. Gastrointestinal symptoms or abdominal pain can occur in the absence of respiratory symptoms. Acute cholestasis and pancreatitis have also been reported in children and adolescents $[23,24]$.

The gravity of the symptoms depends on the clinical stage of the infection $[25,26]$. Moderate infection has been reported as pneumonia, without obvious hypoxemia or difficulty in breathing. Clinical signs and symptoms, as well as the thoracic CT, suggest subclinical lung lesions. In cases of severe infection, oxygen saturation is less than $92 \%$, with manifestations of hypoxia [24]. Critical infection is characterized by respiratory failure, shock, encephalopathy, myocardial injury or heart failure, coagulation dysfunction and acute kidney damage, and multiple organ dysfunction [23]. 


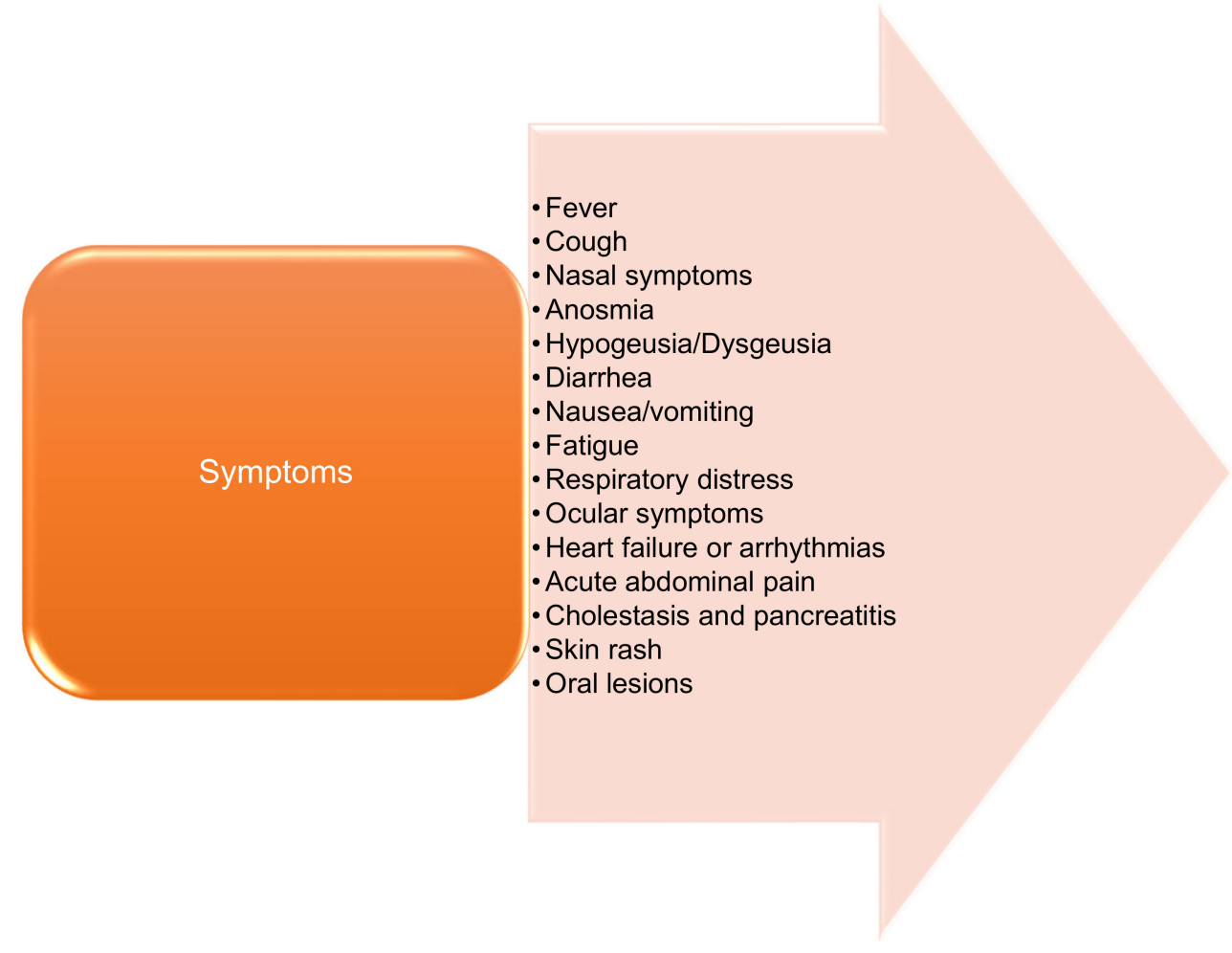

Figure 1. Main symptoms of COVID-19.

\subsection{Severity by Age}

The manifestations of COVID-19 are mostly age-dependent and potentially more severe in cases with involved co-morbidities. The severity of the disease was found to correlate with increasing age [27]. Patients over 65 years of age have a high risk for COVID-19 infection, develop more severe forms, and show increased mortality [19,28,29] due to low immune response [30]. In addition, other factors, such as underlying cardiovascular disease (CVD), may negatively influence the clinical outcome and explain the higher mortality rate, as CVD prevalence increases with age [20]. Older patients show higher incidences of skeletal muscle injury and acute kidney injury [19].

In the early stages of the pandemic, young patients had better clinical outcomes compared to adults, and death rates were lower. In most cases, children diagnosed with COVID-19 developed asymptomatic, mild, or moderate illnesses and recovered one or two weeks after the onset of the disease [23], the clinical symptoms being milder then in adults [26]. Children, even if asymptomatic, can transmit the disease very easily, nasal and fecal secretions being a further challenge for infection control [31].

No differences were identified between young patients and elderly patients in terms of the degree of lung damage [32] but, in elderly patients, the involvement of multiple lobes was higher [29].

As older age groups are vaccinated, children and unvaccinated populations are becoming at higher risk of contracting COVID-19, and developing severe illness. Furthermore, the more contagious Delta strain, which is dominant at present, seems to be impacting younger age groups more than previous variants, despite the fact that does not specifically target children [33].

\subsection{Skin Involvement}

The systemic conditions may be accompanied by skin lesions in which the innate immune system is involved [34,35]. Associated immune-mediated skin diseases, such as psoriasis, atopic dermatitis, and suppurative hidradenitis, have been reported [36,37].

The skin lesions most often associated with COVID-19 are morbilliform, perniolike, urticarial, macular erythematous, vesicular, and papulosquamous lesions, as well as 
retiform purpura and chilblains [38-45]. Skin lesions such as maculopapular lesions and urticarial and vesicular eruptions, as well as transient livedo reticularis and acral peeling, are also frequently mentioned. In children and young adults, red-purple nodules have also been described on distal figures (sometimes called "COVID toes"), similar in appearance to perblio (chilblains) [46].

Skin manifestations are often accompanied by mucosal damage. Extensive skin lesions over the fleshy portion of the buttocks and on the mucosa of the nostrils, tongue, lips, and urethra were reported in hospitalized COVID-19 patients, despite the minimal exposure to pressure. Their extent suggests an inflammatory vascular process beyond pressure-related skin damage [47].

\section{Oral Lesions Related to COVID-19}

This narrative review is focused on presenting the most relevant data from the literature regarding oral manifestations related to SARS-CoV-2, as well as the challenges faced by the dental system during this pandemic.

An electronic search was conducted in PubMed, Scopus, and Web of Science for studies published up to April 2021, with the following keywords used: "oral lesions", "mucosal lesions", "COVID-19", OR "SARS-CoV-2". The full-text articles were evaluated, and the references cited by the relevant studies were further manually searched. Given the available data limited, only literature reviews were excluded. Articles for which the full text was not accessible or not available in English were also excluded.

Reports of different oral manifestations related to COVID-19 cases were described in the literature. Oral lesions reported in patients with COVID-19 were quite heterogeneous (Table 1), varying in the kind of lesion and location. In most cases, the pathogenesis of these manifestations was not clearly defined, being categorized as a direct result of the viral infection, a consequence of immune misbalance, or an adverse reaction to treatment [47-49]. Poor oral hygiene in hospitalized or quarantined COVID-19 patients should also be considered as an aggravating condition [50].

Amorim dos Santos et al. [51] described the case of multiple oral lesions in a 67-yearold man diagnosed with COVID-19. After 20 days of hospitalization, a persistent white plaque on the tongue dorsum was detected and diagnosed as fungus infection. This lesion was treated with intravenous fluconazole and oral nystatin, without any result. Multiple yellowish pinpoint ulcers, diagnosed as recurrent oral herpes, were also present on the tongue dorsum. A fibroma, about $1 \mathrm{~cm}$ in diameter, in the lower lip, related to previous conditions, was also observed. The tongue scraping culture presented Saccharomyces cerevisiae. These conditions were accompanied by extremely viscous saliva. As treatment, antifungals were administered and chlorhexidine digluconate $(0.12 \%)$ non-alcoholic mouthwashes and daily applications of $1 \%$ hydrogen peroxide were performed. After 2 weeks, the lesions showed an almost complete remission, but severe, asymptomatic geographical tongue was observed, according to the severity index [52]. Ten days after removing the patient from hospital, the geographical tongue was still present, but it was reclassified as moderate according to the severity index. [52] The authors suggested that the oral lesions, coinfections, and secondary manifestations may have been due to systemic condition of the patient.

Ansari et al. [53] presented two cases, a 75-year-old male and a 56-year-old female, involving several painful ulcers with irregular margins and varying sizes, with red and nonhemorrhagic backgrounds, located on the hard palate and anterior region of the tongue, respectively. In case 1, the lesions appeared five days after the onset of the symptoms and, in case 2, one week after hospitalization. The diagnostic was of diffuse edema with desquamation, granulation, and ulceration under the mucosa and with invasion of mononuclear and neutrophilic cells, indicating a secondary bacterial infection. The serologic tests for herpes simplex virus (HSV-1 and HSV-2) were negative. The treatment consisted of diphenhydramine, dexamethasone, tetracycline, and lidocaine, and complete 
recovery was obtained after approximately 7 days. The authors suggested that the oral lesions were due to COVID-19.

Bezerra et al. [54] reported a case of a 33-year-old male patient, treated with ivermectin and azithromycin for suspicion of COVID-19, who developed a painful mouth ulceration in the floor of mouth. After 10 days of topical application of corticosteroids, the lesion showed full remission. After twenty days, ageusia was still present, and two other crateriform ulcers with a necrotic background and no erythematous halo were detected in the left retromolar region and lip mucosa. The patient did not report any history of recurrent aphthous ulceration. After 7 days of topical treatment with triamcinolone acetonide and $0.12 \%$ chlorhexidine digluconate mouthwash, the oral ulcerations showed total remission.

Brandao et al. [55] presented eight cases of different oral manifestations in patients with COVID-19.

Case 1. A case of an 81-year-old male, presenting multiple painful, shallow aphthouslike ulcers with irregular margins covered with mucopurulent membrane in the mucosa of the upper and lower lips, as well as in the anterior tongue dorsum, was reported. HSV-1 was identified by saliva testing. Treatment with intravenous acyclovir three times a day for 10 days showed no clinical improvement. To relieve the pain caused by oral ulcers, photobiomodular (PBMT) therapy was performed for 10 days. The symptoms improved after 2 days and after 11 days they were completely resolved.

Case 2. A 71-year-old female presented small hemorrhagic ulcerations on the upper and lower lips. Focal areas of superficial necrosis on the anterior tongue dorsum, developed at the time of hospitalization, were also observed. Following the PCR saliva test, HSV-1 was identified. Intravenous acyclovir was administrated three times a day for 7 days, without any results. Pain was treated with PBMT and regression was observed after 10 days of light therapy, but the lip ulcers did not heal even after 15 days of therapy.

Case 3. In the case of an 83-year-old female, the oral examination revealed an ulcer of $1.5 \times 1.5 \mathrm{~cm}^{2}$ on the right lateral edge of the tongue, accompanied by a petechiae and a superficial necrotic area in the anterior hard palate. These lesions were painful. Following the PCR test, a negative result was obtained for the HSV-1. After 5 days of PBMT treatment, the pain started to diminish, with remission after 10 days.

Case 4 . The case of a 72-year-old male with small hemorrhagic ulcerations affecting the upper and lower lips and a painful necrotic ulceration on the mucosa of the lower right lip, detected a few days after hospitalization, was described. The HSV-1 was detected following the PCR test. The patient received intravenous acyclovir treatment for 7 days, but no improvement was observed. The painful oral necrotic ulcers were treated with PBMT, and regression was observed after 7 days of light therapy.

Case 5. A 32-year-old female, isolated at home with a mild form of COVID-19, showed multiple ulcers on the tip and lateral edges of the tongue, after 10 days of treatment. A teleconsultation was performed by a dentist, following which small superficial and circular lesions with a whitish center and surrounded by an erythematous halo were observed. The patient had no history of recurrent oral ulcers, oral inflammatory diseases, or allergies. After 14 days, the patient recovered from COVID-19 and 8 days later the oral lesions showed remission.

Case 6. Another case was that of a 35-year-old male, quarantined at home, who presented ageusia 6 days later and an oral ulcer on the tonsillar pillar, which caused mild odynophagia. Following the teleconsultation, the following information was obtained: this was the patient's first episode of oral ulcers and he had no history of recurrent aphthous stomatitis or any other ulcerative disease of the mouth. The lesion was superficial and circular, covered by a fibrinopurulent membrane and surrounded by an erythematous halo. After 14 days of isolation the patient recovered completely.

Case 7. A 29-year-old male, isolated at home, presented ageusia on the sixth day of isolation. At teleconsultation, a superficial, painful ulcer, with a diameter of $1 \mathrm{~cm}$ and a whitish pseudomembrane, surrounded by an erythematous halo, was detected on the ventral portion of the tongue. After 6 days the patient recovered. 
Case 8. Another 28-year-old male was placed in isolation at home; after 2 days of isolation, ageusia developed and, after 8 days, aphthous-like ulcers in the upper and lower labial mucosae were observed. After 2 days, another ulcer was observed on the right side of the tongue. The recommended treatment was $0.12 \%$ non-alcoholic chlorhexidine mouthwash. The oral lesions healed completely after 9 days.

The authors' opinion was that the oral manifestations were directly associated with COVID-19 infection and/or the severely compromised state of the patients.

Cebeci Kahraman and Caskurlu [56] described a case of a 51-year-old male patient, treated with clarithromycin $500 \mathrm{mg}$ b.i.d., who reported worsened sore throat symptoms 10 days after the onset. The oral examination revealed a largely erythematous surface in the oropharynx, a few petechiae on the hard palate, and numerous pustular enanthema, 1-3 $\mathrm{mm}$ in diameter, near the soft palate border, more prominent on the left side. The lesions resolved after a few days of antibiotherapy. The authors suggested that oral mucosa may be involved in COVID-19 symptoms.

Chaux-Bodard et al. [48] described the case of a 45-year-old female patient who presented an irregular asymptomatic ulcer on the tongue dorsum following a painful inflammation of a tongue papilla, which evolved in an erythematous macula. After 10 days, the ulcer showed complete remission. Three days after the debut of the oral lesion, a painful erythematous plane lesion also appeared on the big toe, which became asymptomatic after 2 days. The authors suggested that the macular erythematous lesion could be explained by vasculitis, an inflammatory reaction to COVID-19. Thus, the irregular oral ulcer could be considered as an inaugural symptom of COVID-19.

Ciccarese et al. [57] described the case of a previously healthy 19-year-old female, without comorbidities, who had started taking oral cefixime 3 days prior to admission. She reported asymptomatic cutaneous and oropharyngeal lesions that started 2 days before admission. Upon examination, the following lesions were detected: erythematous macules, papules and petechiae on the lower extremities, erosions, ulcerations, and blood crusts on the inner surface of the lips and palatal and gingival petechiae. The oral lesions were painless, heterogeneous in morphology, and associated with severe thrombocytopenia. Intravenous immune globulins and methylprednisolone were administered for 5 days, while antibiotic therapy was stopped. On day 10, the skin and mucosal lesions disappeared. The authors' opinion was that the severe thrombocytopenia was probably of great importance in triggering the cutaneous and mucosal petechiae, while the oral erosions probable cause was direct viral vascular and mucosal damage.

Corchuelo and Ulloa [58] reported a case of a 40-year-old female, diagnosed positive for COVID-19 three weeks before the dental teleconsultation and treated with azithromycin. She presented painless reddish plaques on the lower lip and dark brown pigmentation of the gingiva. A whitish area was detected on the tongue dorsum, apparently accompanied by bacterial plaque. A well-defined brown band was observed in the attached gingiva, which did not transgress the mucogingival junction and partially affected the interpapillary gingiva. A painful aphthous ulcerative lesion on the attached lower left gingiva at the level of the first premolar was also detected. Petechiae were present on the upper part of the face. As treatment, nystatin oral suspension was prescribed, as well as rinses with chlorhexidine gluconate $0.12 \%$ and more frequent brush changes. Another dental teleconsultation was performed after 20 days: the recovery of the lesions of the lips was observed, no aphthous ulcers were present, and the whitish color of the tongue was significantly reduced. The melanin pigmentation in the attached gingiva of the anterior teeth was explained by the proliferation of melanocytes in that part of the body, as an inflammatory process induced by SARS-CoV-2.

Cruz Tapia et al. [59] reported a series of four cases with different oral manifestations.

Case 1. A 41-year-old female in home isolation, who had tested positive for SARS-CoV-2 and was treated with acetaminophen and fexofenadine, described discomfort in the palate. The clinical examination revealed an erythematous, asymptomatic, 6-mm-diameter, soft-consistency, nonbleeding bulla on the hard palate, diagnosed as an angina bullosa 
hemorrhagic-like lesion. The authors' opinion was that the lesions were probably associated with COVID-19 and self-control measures were recommended.

Case 2. A hospitalized 51-year-old female presented diffuse vascular-like purple macule, $12 \mathrm{~mm}$ in size, on the left palatal mucosa and papule plaque of $8 \mathrm{~mm}$ on the right palatal mucosa. Dexamethasone, azithromycin, and indomethacin were administrated. The lesions, non-bleeding and asymptomatic, were considered a vascular disorder, probably associated with COVID-19.

Case 3. A 55-year-old female, isolated at home and treated with acetaminophen, noticed an enlargement of the tongue. Clinical examination revealed an asymptomatic purple bulla, $8 \mathrm{~mm}$ in diameter and of soft consistency, on the right side of the tongue, diagnosed as an angina bullosa hemorrhagic-like lesion, probably associated with COVID-19. The lesion presented a complete remission after 5 days.

Case 4. A 42-year-old male, confirmed positive for SARS-CoV-2, described associated burning-mouth symptoms. The oral examination showed multiple and irregular reddish macules, of 3-4 mm in diameter and indurated consistency, on the hard palate, and a nonspecific mucositis was considered. The patient received acetaminophen for 5 days, and clorhexidine $0.12 \%$ mouthwash was recommended. As the oral lesions persisted, after 14 days, an incisional biopsy was performed, leading to the diagnosis of mucosal, nonspecific, localized vasculitis and thrombosis associated with COVID-19. Topical mometasone furoate $0.1 \%$ and clorhexidine $0.12 \%$ mouthwash were prescribed, and after 7 days of treatment complete remission was observed.

Diaz Rodriguez et al. [60] reported three cases of oral manifestations in patients with confirmed COVID-19.

Case 1. A 43-year-old female was quarantined for 56 days. In the last 2 weeks, she reported aphthous-like lesions, a burning sensation, and tongue depapillation. Rinses with a triamcinolone acetonide $0.05 \%$ solution, three times a day for a 10 -day period, were prescribed. After treatment, lingual depapillation persisted, but the ulcers and burning sensation disappeared.

Case 2. A 53-year-old man, a few days after being discharged from hospital, described a burning-mouth sensation and unilateral commissural fissures. Complaints of dysgeusia were also recorded. Lesions were diagnosed as commissural cheilitis and treated with an ointment containing neomycin, nystatin, and triamcinolone acetonide three times a day. Between ointment applications, use of a gauze with chlorhexidine for local hygiene was also described. Commissural lesions disappeared completely after treatment but dysgeusia persisted.

Case 3. A hospitalized 78-year-old woman reported a very intense sensation of dry mouth. Dental consultation revealed lesions on the tongue, palate, and commissure, compatible with pseudomembranous candidiasis and angular cheilitis. Solutions and gels to improve salivary dryness and nystatin solution rinses four times a day for 15 days were prescribed. Angular cheilitis was treated using ointment containing neomycin, nystatin, and triamcinolone acetonide. After treatment, the pseudomembranous lesions and commissural fissures healed and salivary flow and dry mouth sensation improved.

The authors noted that the cases were related to a certain state of immunosuppression and that stress might have played an important role in the appearance of these oral conditions. The authors' opinion was that a cause-effect relationship between COVID-19 and the oral manifestations could not be established.

Dominguez-Santos et al. [61] presented four cases of young COVID-19 patients who developed minor aphthae during the course of the disease. The patients developed a low number of aphthae (ranging from one to more than five), measuring less than $1 \mathrm{~cm}$, with a creamy-white fibrin surface and an erythematous peripheral ring, mostly affecting the non-keratinized mucosa. Only one patient had a history of recurrent aphthous stomatitis. Tests to exclude secondary causes of aphthosis were performed and PCR testing for HSV was negative. The authors stated that a causal association of oral aphthous ulcers with COVID-19 infection could not be demonstrated. 
Glavina et al. [62] presented the oral manifestations related to COVID-19 in a 40-year-old female with no comorbidities and a history of frequent eruptions of recurrent herpes labialis. Dysgeusia was described as the initial symptom, followed by pain and burning sensation in the oral cavity 7 days after the patient was confirmed positive for SARS-CoV-2. The telemedical consultation revealed recurrent HSV of the hard palate, a white, hairy tongue, and non-specific white lesions of the ventral side of the tongue. Systemic acyclovir therapy was administrated five times a day for 5 days and local therapy (antiseptic, nystatin, panthenol, local anesthetic) for 2 weeks, until complete recovery. The authors opinion was that the recurrent HSV lesions were not caused, but triggered, by SARS-CoV-2 infection, as recurrent oral HSV infection is stress-induced and indicates a compromised immune system.

Jimenez-Cauhe et al. [63] reported cases of three patients who returned to the emergency department because of skin rashes 6,7 , and 4 days after being discharged, respectively. The oral cavity examination revealed palatal macules and petechiae. Following treatment with systemic corticosteroids, the erythema multiforme-like eruption showed progressive resolution after 2-3 weeks. The authors suspected an infectious cause rather than a drug reaction but could not positively exclude the involvement of the various drugs administered.

Kitakawa et al. [64] described the case of a female patient, 20 years old, who tested positive for COVID-19 and was treated with azithromycin and dipyrone. She showed lesions in the median lower lip semimucosa and severe pruritus, with a clinical course of 14 days. These lesions were treated with nebacetin ointment for 2 days, showing a good resolution. After a photographic examination, a differential diagnosis of recurrent herpes was established. The authors' opinion was that it could have been a coincidence; however, the patient did not show any episodes of herpes infection in her history.

Labe et al. [65] described the cases of two children in which the cutaneous manifestations were at the forefront of the clinical picture.

Case 1. A 6-year-old male was hospitalized for painful cheilitis, which developed a week before admission and was followed by a rash of the extremities, and conjunctivitis. Oral examination revealed severe erosive cheilitis with diffuse gingival erosions and thick haemorrhagic crusts. The HSV test was negative. The diagnosis of erythema multiforme was established. As the child's condition improved, he was discharged after 2 weeks.

Case 2. A 3-year-old male, hospitalized, showed cheilitis, stomatitis, and glossitis, accompanied by skin manifestations. After the diagnosis of COVID-19-associated Kawasaki disease was established, an initial dose of intravenous gamma globulin was administrated. Kawasaki disease is a systemic vasculitis with unknown etiology, associated with either viruses or bacteria. The authors stated that this case strongly suggests that SARS-CoV2 is a trigger for Kawasaki disease and supports previous studies focused on possible associations between $\mathrm{HCoV}$ and Kawasaki disease [66,67].

Table 1. Main aspects of the included studies.

\begin{tabular}{|c|c|c|c|c|}
\hline Study & Number of Cases & Patient Data & Oral Lesion & Localization \\
\hline $\begin{array}{l}\text { Amorim dos Santos } \\
\text { et al. [51] }\end{array}$ & 1 & M, 67 , confirmed & $\begin{array}{c}\text { White plaque } \\
\text { Yellowish pinpoint ulcers } \\
\text { Geographical tongue }\end{array}$ & Tongue dorsum \\
\hline Ansari et al. [53] & 2 & $\begin{array}{l}\text { 1. M, 75, confirmed } \\
\text { 2. F, 56, confirmed }\end{array}$ & $\begin{array}{l}\text { Several painful ulcers, with } \\
\text { irregular margins and } \\
\text { varying sizes against red and } \\
\text { nonhemorrhagic } \\
\text { backgrounds }\end{array}$ & $\begin{array}{l}\text { 1. Hard palate } \\
\text { 2. Anterior region of } \\
\text { the tongue }\end{array}$ \\
\hline
\end{tabular}


Table 1. Cont.

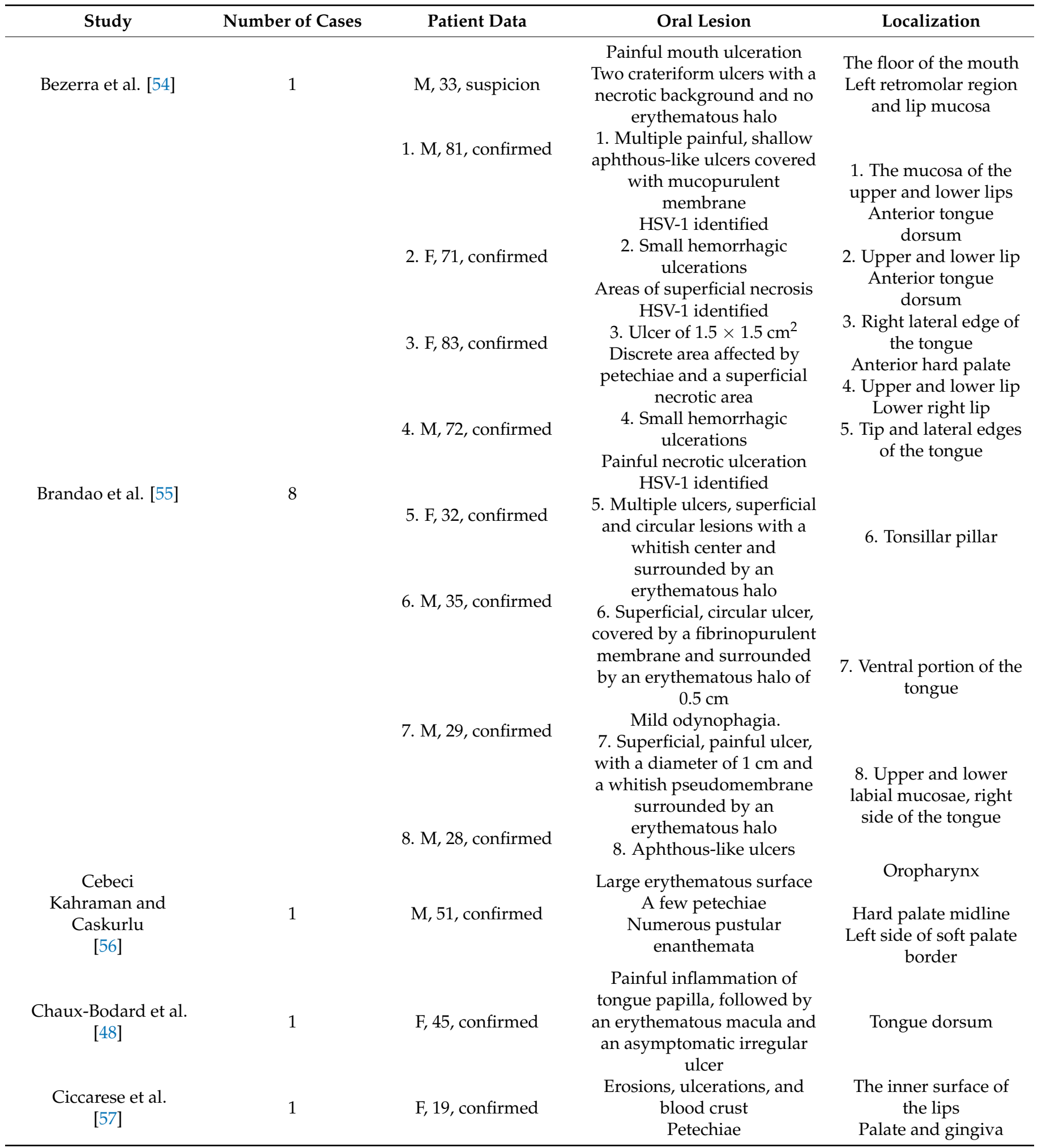


Table 1. Cont.

\begin{tabular}{|c|c|c|c|c|}
\hline Study & Number of Cases & Patient Data & Oral Lesion & Localization \\
\hline \multirow[t]{2}{*}{$\begin{array}{l}\text { Corchuelo and Ulloa } \\
\qquad[58]\end{array}$} & \multirow[t]{2}{*}{1} & \multirow[t]{2}{*}{ F, 40 , confirmed } & $\begin{array}{c}\text { Reddish plaques } \\
\text { Dark brown pigmentation } \\
\text { Aphtous-like ulcer }\end{array}$ & $\begin{array}{c}\text { Lower lip } \\
\text { Gingiva } \\
\text { Attached lower left } \\
\text { gingiva }\end{array}$ \\
\hline & & & White area, probably candida & Tongue dorsum \\
\hline \multirow{3}{*}{ Cruz Tapia et al. [59] } & \multirow{3}{*}{4} & 1. F, 41, confirmed & 1. Bulla & 1. Hard palate \\
\hline & & 2. F, 42 , confirmed & 2. Macule & $\begin{array}{l}\text { 2. Hard palate } \\
\text { (left side) }\end{array}$ \\
\hline & & $\begin{array}{l}\text { 3. F, } 55 \text {, confirmed } \\
\text { 4. } \mathrm{M}, 41 \text {, confirmed }\end{array}$ & $\begin{array}{l}\text { 3. Bulla } \\
\text { 4. Small macule }\end{array}$ & $\begin{array}{l}\text { 3. Tongue } \\
\text { 4. Hard palate }\end{array}$ \\
\hline \multirow{3}{*}{$\begin{array}{l}\text { Diaz Rodriguez et al. } \\
\text { [60] }\end{array}$} & \multirow{3}{*}{3} & 1. F, 43 , confirmed & $\begin{array}{l}\text { 1. Aphthous-like lesions, } \\
\text { burning sensation, and } \\
\text { tongue depapillation }\end{array}$ & 1. N/A \\
\hline & & 2. $M, 53$, confirmed & $\begin{array}{l}\text { 2. Burning-mouth sensation } \\
\text { and unilateral angular } \\
\text { cheilitis }\end{array}$ & 2. Lips \\
\hline & & 3. F, 78 , confirmed & $\begin{array}{l}\text { 3. Pseudomembranous } \\
\text { candidiasis and angular } \\
\text { cheilitis }\end{array}$ & 3. Tongue, palate \\
\hline \multirow{3}{*}{$\begin{array}{l}\text { Dominguez-Santos } \\
\text { et al. [61] }\end{array}$} & \multirow{3}{*}{4} & 1. F, 43 , confirmed & \multirow{2}{*}{$\begin{array}{l}\text { 1. Single ulcer, with } \\
\text { peripheral erythematous rim } \\
\text { 2. Single aphtous ulcer }\end{array}$} & 1. Right buccal mucosa \\
\hline & & 2. $\mathrm{M}, 33$, confirmed & & $\begin{array}{l}\text { 2. Superior } \\
\text { mucogingival junction }\end{array}$ \\
\hline & & 3. $\mathrm{M}, 37$, confirmed & $\begin{array}{l}\text { 3. Seven aphtae } \\
\text { 4. Four clustered aphtae }\end{array}$ & $\begin{array}{l}\text { 3. Ventral right side of } \\
\text { the tongue } \\
\text { 4. Right side of the } \\
\text { inferior labial mucosa }\end{array}$ \\
\hline $\begin{array}{l}\text { Glavina et al. } \\
\text { [62] }\end{array}$ & 1 & F, 40 , confirmed & $\begin{array}{c}\text { Pain and burning in the oral } \\
\text { cavity } \\
\text { Recurent HSV } \\
\text { White, hairy tongue }\end{array}$ & Hard palate \\
\hline $\begin{array}{l}\text { Jimenez Cauhe et al. } \\
\text { [63] }\end{array}$ & 3 & $\begin{array}{l}\text { F, } 77 \text {, confirmed } \\
\text { F, 58, confirmed } \\
\text { F, } 69 \text {, confirmed }\end{array}$ & Macules and petechiae & Palate \\
\hline $\begin{array}{c}\text { Kitakawa et al. } \\
\text { [64] }\end{array}$ & 1 & F, 20, confirmed & Herpetic lesions, pruritus & $\begin{array}{l}\text { Median lower lip } \\
\text { semimucosa }\end{array}$ \\
\hline \multirow[t]{2}{*}{ Labe et al. [65] } & 2 & $\begin{array}{l}\text { 1. M, 6, confirmed } \\
\text { 2. M, 3, suspicion }\end{array}$ & $\begin{array}{l}\text { 1. Painful cheilitis } \\
\text { 2. Cheilitis, stomatitis, } \\
\text { glossitis }\end{array}$ & $\begin{array}{l}\mathrm{N} / \mathrm{A} \\
\mathrm{N} / \mathrm{A}\end{array}$ \\
\hline & \multirow{3}{*}{3} & 1. $M, 56$, suspicion & $\begin{array}{c}\text { 1. Painful lesions resembling } \\
\text { a herpetic recurrent } \\
\text { stomatitis }\end{array}$ & 1. Palate \\
\hline \multirow[t]{2}{*}{$\begin{array}{c}\text { Martin Carreras-Presas } \\
\text { et al. [68] }\end{array}$} & & 2. $M, 58$, suspicion & $\begin{array}{l}\text { 2. Multiple small, painful } \\
\text { yellowish ulcers with } \\
\text { erythematous halo }\end{array}$ & 2. Palate \\
\hline & & 3. $\mathrm{F}, 65$, confimed & $\begin{array}{c}\text { 3. Pain } \\
\text { Blisters } \\
\text { Desquamative } \\
\text { gingivitis }\end{array}$ & $\begin{array}{l}\text { 3. Tongue } \\
\text { Internal lip mucosa } \\
\text { Gingiva }\end{array}$ \\
\hline $\begin{array}{l}\text { Nuno-Gonzalez et al. } \\
\text { [69] }\end{array}$ & 78 & $\begin{array}{c}\text { Adults, average age of } \\
55.7 \text { years, } \\
\text { confirmed/suspicion }\end{array}$ & $\begin{array}{l}\text { Lingual papillitis, glossitis, } \\
\text { aphthous stomatitis, } \\
\text { mucositis, and burning } \\
\text { sensation }\end{array}$ & $\mathrm{N} / \mathrm{A}$ \\
\hline $\begin{array}{l}\text { Patel et al. } \\
\quad[70]\end{array}$ & 1 & F, 35, suspicion & $\begin{array}{l}\text { Erithematous and edematous } \\
\text { gingiva and necrotic } \\
\text { interdental papillae }\end{array}$ & $\begin{array}{l}\text { Gingiva and } \\
\text { interdental papillae }\end{array}$ \\
\hline
\end{tabular}


Table 1. Cont.

\begin{tabular}{|c|c|c|c|c|}
\hline Study & Number of Cases & Patient Data & Oral Lesion & Localization \\
\hline Putra et al. [71] & 1 & M, 29, confirmed & Aphthous stomatitis & $\mathrm{N} / \mathrm{A}$ \\
\hline Riad et al. [72] & 17 & $\begin{array}{c}12 \mathrm{~F}, 5 \mathrm{M} \text {; average age } \\
\text { of } 39.94 \text {, confirmed }\end{array}$ & Angular cheilitis & Lips \\
\hline Riad et al. [73] & 26 & $\begin{array}{c}\text { average age of } 36.81, \\
\text { confirmed }\end{array}$ & Tongue ulcers & Tongue \\
\hline $\begin{array}{l}\text { Sakaida et al. } \\
\text { [74] }\end{array}$ & 1 & F, 52, confirmed & $\begin{array}{l}\text { Erythematous and erosive } \\
\text { lesions }\end{array}$ & Lips and oral mucosa \\
\hline $\begin{array}{l}\text { Soares et al. } \\
\text { [75] }\end{array}$ & 1 & $\mathrm{M}, 42$, confirmed & $\begin{array}{c}\text { Painful ulceration } \\
\text { Multiple reddish macules of } \\
\text { different sizes }\end{array}$ & $\begin{array}{l}\text { Buccal mucosa } \\
\text { Hard palate, tongue, } \\
\text { and lips }\end{array}$ \\
\hline
\end{tabular}

Martin Carreras-Presas et al. [68] presented three cases of oral manifestations associated with COVID-19. In all cases, video consultations were performed.

Case 1. A healthy 56-year-old male patient, suspected of having COVID-19, presented dysgeusia, pain in his palate, and sore throat. Lesions resembling recurrent herpetic stomatitis were detected; however, the patient denied any HSV history. The prescribed treatment was valaciclovir for 10 days, and topical antiseptics with chlorhexidine and hyaluronic acid. After 10 days, the oral lesions showed full recovery.

Case 2. A 58-year-old male patient, suspected of having COVID-19, also reported pain in his palate. Multiple small, yellowish ulcers with an erythematous halo were detected on his palate. The patient did not have any previous history of herpetic infection. After 1 week of using topical antiseptic mouthwash, the painful lesions healed completely.

Case 3. A 65-year-old female patient, hospitalized and treated with antibiotics, corticosteroids, and antiviral drugs, developed a rash after being discharged. She described pain in her tongue from the beginning of the disease but had not been given an intraoral examination. After one week of antifungal administration, blisters in the internal lip mucosa, as well as desquamative gingivitis, could be observed. Hyaluronic acid and chlorhexidine mouthwash were prescribed, as well as prednisolone. The oral lesions improved within 3 days. In the authors' opinion, it can be assumed that SARS-CoV-2 can provoke exanthematic lesions similar to other viral processes usually diagnosed in the dental clinic.

Nuno-Gonzalez et al. [69] provided the results of a cross-sectional study that aimed to evaluate cutaneous findings in 666 COVID-19 patients with mild-to-moderate pneumonia and a mean age of 55.7 years. A total of 304 of them presented one or more mucocutaneous manifestations. Oral manifestations, such as transient lingual papillitis, glossitis with lateral indentations or patchy depapillation, aphthous stomatitis, and mucositis, were also found in 78 cases. A burning sensation was also reported, and dysgeusia was commonly associated. The authors stated that, due to the frequency of the oral lesions, a specific examination was in order to avoid contagion risk.

The case of a 35-year-old female patient, who attended the dental emergency department describing fever, halitosis, intense gingival pain, and bleeding, was described by Patel [70]. Bilateral submandibular lymphadenopathy, severe halitosis, generalized erythematous and edematous gingivae, and necrotic interdental papillae in both the maxillary and mandibular labial sextants were accompanied by unprovoked bleeding from the gingival sulcus. A clinical diagnosis of necrotizing gingivitis was made and treatment with metronidazole three times daily for 5 days and $0.12 \%$ chlorhexidine mouthwash twice daily for 10 days was prescribed. Five days later, complete resolution of oral symptoms and fever was observed. Despite the fact that the patient was not tested and only a suspicion of COVID-19 infection could be stated, the authors emphasized the role of bacterial co-infections in COVID-19 severity.

Putra et al. [71] described a case of a 29-year-old male who presented cutaneous manifestations and was treated with azithromycin, hydroxychloroquine, oseltamivir, vitamin C3, 
and vitamin D1. Stomatitis aphthous, noticed on day seven, with no other treatment besides typical hygiene oral care, showed complete remission on day ten. The diagnosis of hand, foot, and mouth disease was supported by the appearance of stomatitis aphthous.

Riad et al. [72,73] presented two series of cases involving oral manifestations in patients confirmed to be infected with COVID-19.

The first series [72] consisted of 17 confirmed COVID-19 patients with angular cheilitis. The patients had a mean age 39.94 and 12 of them were female. The authors' opinion was that angular cheilitis in COVID-19 patients can be attributed to numerous local irritants, including hypersalivation.

The second case series [73] included 26 confirmed COVID-19 patients with painful tongue ulcers. Their average age was 36.81 , there were 9 males and 17 females, and they were treated with oral paracetamol and chlorhexidine mouthwash. The ulcers disappeared after 1-2 weeks. The authors' opinion was that tongue ulcers can be a direct manifestation of SARS-CoV-2 infection or a co-infection due to the immune dysregulation.

Sakaida et al. [74] presented a case of a 52-year-old woman with itchy erythematous lesions on her limbs after being treated for 3 days with antibiotics and a non-steroid antiinflammatory drug for previous dental problems. After 2 days of treatment, erosions on her lips and buccal mucosa appeared. The skin lesions were clinically diagnosed as a drug eruption. Oral prednisolone was administrated to treat oral lesions, which gradually improved. Five days after decreasing the prednisolone, symptoms of SARS-CoV-2 appeared and the patient tested positive. The authors' opinion was that the drug eruption during the latency period might have been related to a COVID-19-induced cytokine storm.

Soares et al. [75] reported a case of a 42-year-old male patient, confirmed positive for SARS-CoV-2, who developed reddish oral lesions and a painful ulceration in the buccal mucosa, associated with petechia-like skin and small vesicobullous lesions of unknown etiology. The multiple reddish macules of different sizes were scattered along the hard palate, tongue, and lips. A treatment with dexamethasone and dipyrone was established for 1 week, and after 3 weeks the lesions presented complete remission. The authors suggested that SARS-CoV-2 can cause oral lesions and therefore that all positive patients should have a full mouth check-up.

The general aspects of the abovementioned studies are summarized in Table 1.

According to the reviewed data, the most frequent types of oral lesions found in COVID-19 patients are: ulcers (42 cases, 25.92\%), aphthous stomatitis/aphtae (29 cases, $17.90 \%$ ), angular cheilitis/cheilitis (21 cases, $12.96 \%$ ), glossitis/lingual papillitis (21 cases, $12.96 \%)$, petechiae ( 8 cases, $4.93 \%)$, macules ( 7 cases, $4.32 \%)$, erythematous and erosive lesions ( 6 cases, $3.70 \%$ ), herpetic lesions ( 6 cases, $3.70 \%$ ), candidiasis ( 4 cases, $2.46 \%$ ), and bulla ( 2 cases, $1.23 \%)$.

\section{The Association between Periodontal Disease and COVID-19}

Periodontal disease, a severe inflammatory gum disease, mainly affects the supporting structures of the teeth, gingiva, and alveolar bone, and it is frequently associated with poor oral hygiene and age. As the human organism normally responds to bacterial infection through inflammation, this process can result in a "cytokine storm", where proteins are released and associated with an exuberant inflammatory response that destroy tissues in other parts of the body [76].

The inflammatory products can enter the bloodstream through periodontal pockets and reach other organs, causing tissue damage [77]. Pro-inflammatory cytokines and oxidative stress, involved in the development of periodontal disease and other metabolic diseases, are highly elevated among COVID-19 patients [78]. Bacteria in the gums spread the IL-6 inflammatory protein. High levels of IL-6 in the body are a predictor of respiratory failure, with a 22 times higher risk for respiratory complications being reported, thus highlighting the importance of reducing the amount of oral bacteria and subsequent systemic inflammation [79]. 
On the other hand, the high prevalence of periodontal disease among patients experiencing metabolic diseases, such as obesity and diabetes, and cardiovascular diseases is well-documented. These types of comorbidities, which affect systemic health, are also known to increase the risk for severe COVID-19 [80-82]. The association between periodontal disease and severe COVID-19 could help identify risk groups and establish pertinent recommendations [83].

A study on 568 patients, showed a clear association between periodontitis and increased levels of biomarkers associated with severe COVID-19 disease, as well as complications including death, ICU admission, and the need for assisted ventilation [84].

The investigations of a possible link between the microbial oral flora and COVID-19 also revealed that there is a risk that oral secretions may be aspirated into the lungs and cause infection [85]. Oral bacteria, such as the periodontal pathogens Porphyromonas gingivalis, Fusobacterium nucleatum, and Prevotella intermedia, may accelerate viral infectious diseases such as COVID-19 and aggravate lung damage [50]. Cytokines such as interleukin 1 (IL1) and tumor necrosis factor (TNF), which are present in the saliva as a consequence of their bacterial activity, can easily reach the lungs [84].

Poor oral hygiene, a frequent consequence of low income or psychological troubles, can lead to COVID-19 aggravation due to the aspiration of periodontopathic bacteria, which induces the expression of ACE-2, a known receptor for SARS-CoV-2, and the production of inflammatory cytokines in the lower respiratory tract. Long-term hospitalization of patients with COVID-19 leads to reduced professional oral care. Poor oral hygiene, and limited access to dental care in patients with COVID-19, may increase the inter-bacterial exchanges between the oral cavity and the lungs and thus the risk of a much more severe respiratory infection [86-88].

The degree of periodontal inflammation may help to determine the severity of COVID19 infection. Routine dental and periodontal treatment may also help decrease the symptoms of COVID-19 [50,85]. The link between poor oral hygiene, bacteria present in the oral cavity, and increased risk of lung damage is presented in Figure 2.

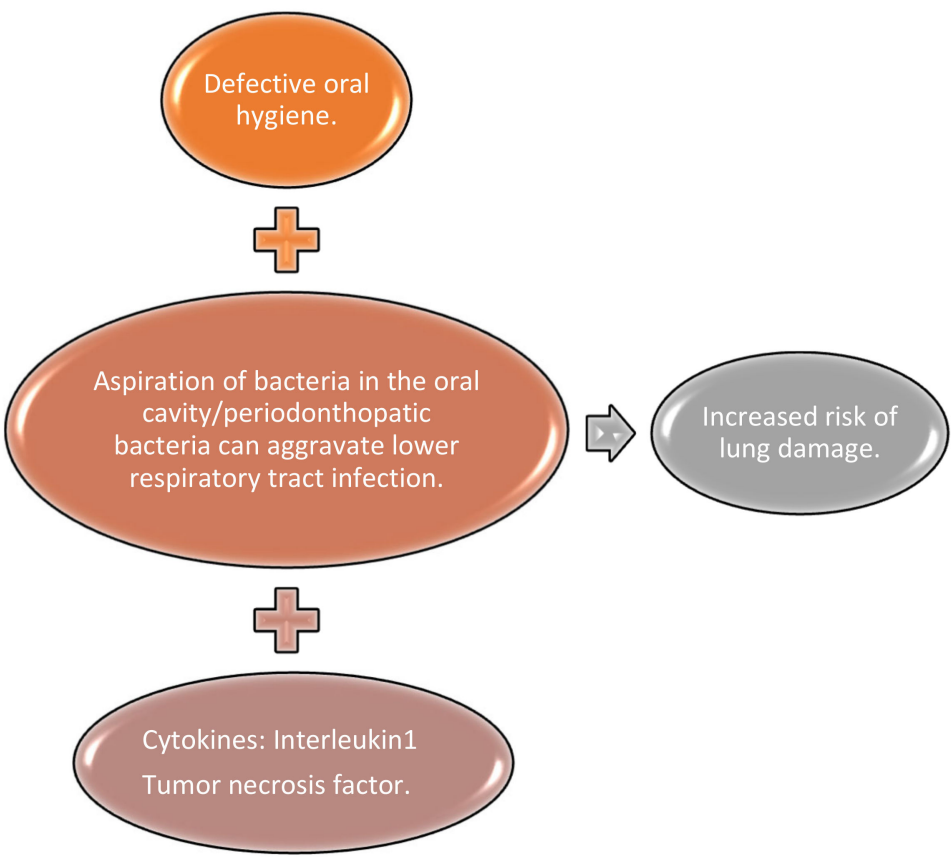

Figure 2. The link between poor oral hygiene, bacteria present in the oral cavity, and increased risk of lung damage.

\section{Temporomandibular Disorders Associated with COVID-19 Pandemic}

Among the most common symptoms of temporomandibular disorders (TMDs) are soreness in the jaw joint area and jaw muscles and clicking or crunching noises when 
opening or closing the mouth or when the patient chews, yawns, or even speaks. TMD may be linked with headaches, neck pain, and discomfort in the temple or teeth. TMD reflects the dysfunction of the masticatory system, one of its major causes being stress and psychosocial impairment [89].

Pandemics are stressful, like most public health emergencies. The literature presents aspects of psychological reactions related to epidemics and pandemics, which depend on individual vulnerability, intolerance to uncertainty, perceived vulnerability to disease, and anxiety [90]. The anxiety, depression, and stress people experience during the COVID-19 pandemic may lead to TMD [91].

Uncertainties about the origin and nature of the virus and about governments' abilities to prevent its spread, lack of confidence in the medical system and its ability to cope with new cases, fear of infection, misinformation, and feelings of loneliness and anger in quarantined people due to lack of socialization play important roles in the development and maintenance of TMD [92].

These psychosocial factors, often associated with sympathetic activity and additional release of adrenocortical steroids, may lead to muscle vasoconstriction and increased peripheral vascular resistance. Autonomic insufficiency can increase the sympathetic impulse and the feeling of hyper-excitement that creates and perpetuates sleep disorders, accompanied by sensations such as heat and cold, palpitations, tachycardia, nausea, abdominal pain, diarrhea, and constipation [93].

Reports have noted an increased number of people experiencing teeth grinding and oral pain during the COVID-19 pandemic as a consequence of increased stress due to health worries, the loss of work, and lockdown or separation from family members [94,95]. On the other hand, stress, anxiety, and depression due to COVID-19 lead to increased orofacial pain, TMD, and bruxism symptoms [96,97].

According to another recent study, people with chronic TMD are more susceptible to COVID-19 distress, resulting in deterioration of their psychological status, and increased chronic facial pain severity, supporting the hypothesis that stress acts as an amplifier of central sensitization, anxiety, depression, chronic pain, and pain-related disability in TMD cases [98].

Two concomitant studies aimed to evaluate the effect of lockdown on TMD and bruxism symptoms among 700 subjects from Israel and 1092 from Poland, respectively, by using online questionnaires. The results showed significant altered psychoemotional status, leading to aggravated bruxism and TMD symptoms, accompanied by increased orofacial pain [97].

Even after the lockdown period ended, patients with high risk for severe COVID-19 limited their dental appointments to emergencies only, which was not the case for TMD and bruxism. As they were neglected, these conditions got worse [99].

Medical staff, including dental practitioners, have also been reported to experience moderate to severe levels of anxiety because of possible COVID-19 repercussions [90,94,100].

A study carried out on 641 dental surgeons found TMD in $24.3 \%$ of the participants, sleep bruxism in 58\%, and awake bruxism in 53.8\% [101]. The incidence of TMD reported by a study carried out on 699 dental university students during the COVID-19 pandemic was of $77.5 \%$, accompanied by impaired sleep quality, depression, anxiety, and stress [102]. Another study, based on 113 questionnaires filled out by dental students, also reported that the social isolation and stress due to the COVID-19 pandemic had led to increase symptoms of TMD, anxiety, and depression [103].

\section{Dental Medicine during the COVID-19 Pandemic}

Health systems around the world were subjected to a great challenge due to the rapid spread of SARS-CoV-2 and the related COVID-19 pneumonia until the vaccine became available. The public health measures during the pandemic forced patients with and without SARS-CoV-2 to remain isolated in order to prevent the spread. The majority of 
the patients were unable to attend dental services, postponed the appointments, and even neglected their oral hygiene, which can lead to complications [58].

At the beginning of the pandemic, dentistry, as well as oral and maxillofacial surgery and dental radiology, were included among the groups with the highest risk of infection due to inevitable close contact with SARS-CoV-2 asymptomatic and symptomatic patients [104,105].

Dental staff may develop an increased risk of infection due to the proximity of patients, who cannot wear masks during treatment and keep their mouth open [106]. The high risk is also caused by instruments and equipment that generate aerosols that contain oral and respiratory fluids, such as high-speed and ultrasonic scaling devices, both of which use a water-coolant [86,106-108]. Dental radiology, which does not allow the use of a rubber dam, is equally risky, as the patient may cough or gag if the image receptor is placed deep inside the mouth [109].

The high viral load in the nasal cavity in infected patients, even if asymptomatic, puts dentists and maxillofacial surgeons at even higher risk for SARS-CoV-2 infection because of the close contact. Treating patients in these pandemic times has to be undertaken with maximum precautions in order to minimize the infection transmission [110-112].

For a determined period of time at the beginning of the pandemic, dental practices were closed and only dental emergencies that could not be postponed [95] or facial trauma surgery were performed $[112,113]$.

The most common types of facial trauma, generally caused by road or sports accidents, were reduced during this period because of the imposed restrictions, but trauma caused by domestic violence or falls still occurred. Oral and maxillofacial surgeons, head and neck surgeons, and plastic surgeons managed both facial trauma and patient triage by performing COVID-19 buffer tests and helping intubate COVID-19-positive patients with facial trauma [110].

During the peak of the pandemic, when personal contact was avoided as much as possible, telemedicine proved to be a useful tool in dental diagnosis $[60,112]$.

Later on, specific protocols were implemented, combining sanitizing procedures with the wearing of disposable personal protective equipment (PPE). Patient screening by telephone, before scheduling a dental appointment, has been considered necessary to prevent spreading the virus inside the dental office $[114,115]$.

At their arrival, patients must wear a surgical mask and must be unaccompanied (when possible). Patients are requested to leave any personal belongings in certain spaces and sanitize their hands, and they are provided with PPE.

The dental staff have to be equipped with disposable personal protective equipment: gloves, filtering facepiece particle 2 (FFP2) respirator, visor, protective gown, and shoe covers $[116,117]$.

In order to reduce the presence of the virus in the saliva, rinsing with a mouthwash for at least $30 \mathrm{~s}$ prior to starting the dental treatment has been advised [118].

During clinical procedures, the use of a rubber dam is strongly recommended to limit the spread of aerosols and potentially infected biological material. The procedures which might cause coughing or gagging must be avoided; for example, the use of an intra-oral scanner instead of a conventional dental impression is preferred [109].

The type of aspirating system used seems to affect the prevalence of SARS-CoV-2 infection across dental offices. Using aspirating systems equipped with HEPA filters, capable of evacuating and dissipating aerosols into specialized areas, is strongly recommended [119].

At the end of the dental appointment, all disposable PPE must be properly discarded [120].

Accurate sanitizing of hands and of all surfaces is equally important, as well as proper ventilation for patients [120-122].

Radiography practices should be kept as simple as possible and minimize staff-topatient contact. Intraoral radiographs should be avoided as much as possible during the COVID-19 pandemic. Extraoral bitewings represent an alternative for sectional panoramic radiographs and intraoral bitewings. Extraoral bitewings, which involve a radiation dose 
lower than or comparable to intraoral radiographs while providing a greater field of view, could be further considered, especially in cases of children and adults with difficulties in tolerating intraoral radiographs [123].

\section{Conclusions and Future Perspectives}

Oral manifestations related to COVID-19, including fungal infections, recurrent HSV, oral ulcerations, drug-related eruptions, dysgeusia, xerostomia or decreased salivary flow, and gingivitis, may be a result of the impaired immune system and/or susceptible oral mucosa [124].

Although, it is difficult to state which of the various oral lesions associated with COVID-19 are the most prevalent, it seems that a higher frequency can be found in older, hospitalized patients with severe infection [125].

A number of factors, such as immune impairment, co-morbidities, poor oral hygiene, adverse drug reactions, stress, secondary hyper-inflammatory responses, and iatrogenic trauma following intubation, may be involved [126].

The hypothesis that the oral manifestations are secondary lesions resulting from the deterioration of systemic health or treatments for COVID-19 is most probably correct. The pharmacological agents against COVID-19 are related to several adverse reactions, including oral lesions [127].

The authors of one study stated that "The oral mucosal examination has been neglected during the pandemic on reasonable grounds" [56]. A routine intraoral examination should always be performed on patients with suspected or confirmed SARS-CoV-2 infection, as it can represent a sign of potentially life-threatening conditions $[57,70]$.

It has also been stated that "Whether the currently emerging new viral variants will have an impact on the oral manifestations is unknown" [125]. It is our belief that extensive knowledge about all possible manifestations in cases of COVID-19, including oral lesions, is of great importance in the present uncertain context. The fourth wave of COVID-19 and the alarming spreading of the Delta strain, which is highly contagious and potentially severe, keep the subject actual; skin manifestations are increasingly frequent. It can be assumed, based on the correlation between skin and oral manifestations, that new outcomes regarding this subject will emerge.

Dentists are not only implicated in providing specialty assistance in times of pandemics but also in fighting against them. A special note that seems worth mentioning is that, during the anti-COVID-19 vaccination campaign in Romania, marathon vaccinations were carried out during weekends in an effort to encourage attendance and limit the spread of the pandemic. Dentists took part as volunteers, together with fellow doctors and students, and 6722 people were vaccinated in the authors' hometown during the first organization of this marathon series.

Author Contributions: Conceptualization, L.-C.R. and L.C.A.; methodology, L.-C.R.; validation, L.-C.R. and L.C.A.; formal analysis, A.M. and C.V.T.; investigation, I.S., E.A.B. and L.C.A.; writingoriginal draft preparation, I.S., E.A.B. and L.C.A.; writing-review and editing, L.C.A.; visualization, L.-C.R. and L.C.A.; supervision, L.-C.R. and L.C.A.; project administration, L.-C.R. and L.C.A. All authors have read and agreed to the published version of the manuscript.

Funding: This research received no external funding.

Institutional Review Board Statement: Not applicable.

Informed Consent Statement: Not applicable.

Conflicts of Interest: The authors declare no conflict of interest. 


\section{References}

1. Weiss, S.R.; Leibowitz, J.L. Coronavirus Pathogenesis. Adv. Appl. Microbiol. 2011, 81, 85-164. [CrossRef]

2. Hui, D.S.; Azhar, E.I.; Memish, Z.A.; Zumla, A. Human Coronavirus Infections-Severe Acute Respiratory Syndrome (SARS), Middle East Respiratory Syndrome (MERS), and SARS-CoV-2. In Encyclopedia of Respiratory Medicine; Elsevier BV: Amsterdam, The Netherlands, 2021; pp. 146-161.

3. Ramadan, N.; Shaib, H. Middle East respiratory syndrome coronavirus (MERS-CoV): A review. Germs 2019, 9, 35-42. [CrossRef] [PubMed]

4. Liu, Y.; Yang, Y.; Zhang, C.; Huang, F.; Wang, F.; Yuan, J.; Wang, Z.; Li, J.; Li, J.; Feng, C.; et al. Clinical and biochemical indexes from 2019-nCoV infected patients linked to viral loads and lung injury. Sci. China Life Sci. 2020, 63, 364-374. [CrossRef] [PubMed]

5. Zhou, P.; Yang, X.-L.; Wang, X.-G.; Hu, B.; Zhang, L.; Zhang, W.; Si, H.-R.; Zhu, Y.; Li, B.; Huang, C.-L.; et al. A pneumonia outbreak associated with a new coronavirus of probable bat origin. Nature 2020, 579, 270-273. [CrossRef]

6. Ge, H.; Wang, X.; Yuan, X.; Xiao, G.; Wang, C.; Deng, T.; Yuan, Q.; Xiao, X. The epidemiology and clinical information about COVID-19. Eur. J. Clin. Microbiol. Infect. Dis. 2020, 39, 1011-1019. [CrossRef] [PubMed]

7. Shi, J.; Wen, Z.; Zhong, G.; Yang, H.; Wang, C.; Huang, B.; Liu, R.; He, X.; Shuai, L.; Sun, Z.; et al. Susceptibility of ferrets, cats, dogs, and other domesticated animals to SARS-coronavirus 2. Science 2020, 368, 1016-1020. [CrossRef] [PubMed]

8. Zheng, J. SARS-CoV-2: An Emerging Coronavirus that Causes a Global Threat. Int. J. Biol. Sci. 2020, 16, 1678-1685. [CrossRef]

9. Guarner, J. Three Emerging Coronaviruses in Two Decades. Am. J. Clin. Pathol. 2020, 153, 420-421. [CrossRef]

10. Hu, B.; Guo, H.; Zhou, P.; Shi, Z.-L. Characteristics of SARS-CoV-2 and COVID-19. Nat. Rev. Microbiol. 2021, 19, 141-154. [CrossRef]

11. World Health Organization. Novel Coronavirus (2019-nCoV) Situation Report-22-Data as Reported by 11 February 2020. Available online: https:/ / www.who.int/docs/default-source/coronaviruse/situation-reports/20200211-sitrep-22-ncov.pdf? sfvrsn=fb6d49b1_2 (accessed on 15 June 2021).

12. Naqvi, A.A.T.; Fatima, K.; Mohammad, T.; Fatima, U.; Singh, I.K.; Singh, A.; Atif, S.M.; Hariprasad, G.; Hasan, G.M.; Hassan, I. Insights into SARS-CoV-2 genome, structure, evolution, pathogenesis and therapies: Structural genomics approach. Biochim. Biophys. Acta BBA Mol. Basis Dis. 2020, 1866, 165878. [CrossRef] [PubMed]

13. Harrison, A.G.; Lin, T.; Wang, P. Mechanisms of SARS-CoV-2 Transmission and Pathogenesis. Trends Immunol. 2020, 41, 1100-1115. [CrossRef] [PubMed]

14. Zou, X.; Chen, K.; Zou, J.; Han, P.; Hao, J.; Han, Z. Single-cell RNA-seq data analysis on the receptor ACE2 expression reveals the potential risk of different human organs vulnerable to 2019-nCoV infection. Front. Med. 2020, 14, 185-192. [CrossRef] [PubMed]

15. Xu, H.; Zhong, L.; Deng, J.; Peng, J.; Dan, H.; Zeng, X.; Li, T.; Chen, Q. High expression of ACE2 receptor of 2019-nCoV on the epithelial cells of oral mucosa. Int. J. Oral Sci. 2020, 12, 8. [CrossRef] [PubMed]

16. Chen, Y.; Liu, Q.; Guo, D. Emerging coronaviruses: Genome structure, replication, and pathogenesis. J. Med. Virol. 2020, 92, 418-423. [CrossRef] [PubMed]

17. Azkur, A.K.; Akdis, M.; Azkur, D.; Sokolowska, M.; Van De Veen, W.; Brüggen, M.-C.; O’Mahony, L.; Gao, Y.; Nadeau, K.; Akdis, C.A. Immune response to SARS-CoV-2 and mechanisms of immunopathological changes in COVID-19. Allergy 2020, 75, 1564-1581. [CrossRef] [PubMed]

18. Shah, V.K.; Firmal, P.; Alam, A.; Ganguly, D.; Chattopadhyay, S. Overview of Immune Response During SARS-CoV-2 Infection: Lessons From the Past. Front. Immunol. 2020, 11, 1949. [CrossRef]

19. Wei, C.; Liu, Y.; Liu, Y.; Zhang, K.; Su, D.; Zhong, M.; Meng, X. Clinical characteristics and manifestations in older patients with COVID-19. BMC Geriatr. 2020, 20, 1-9. [CrossRef] [PubMed]

20. Sciacqua, A.; Pujia, R.; Arturi, F.; Hribal, M.L.; Montalcini, T. COVID-19 and elderly: Beyond the respiratory drama. Intern. Emerg. Med. 2020, 15, 907-909. [CrossRef]

21. Cui, X.; Zhao, Z.; Zhang, T.; Guo, W.; Guo, W.; Zheng, J.; Zhang, J.; Dong, C.; Na, R.; Zheng, L.; et al. A systematic review and meta-analysis of children with coronavirus disease 2019 (COVID-19). J. Med. Virol. 2021, 93, 1057-1069. [CrossRef]

22. Panahi, L.; Amiri, M.; Pouy, S. Clinical Characteristics of COVID-19 Infection in Newborns and Pediatrics: A Systematic Review. Arch. Acad. Emerg. Med. 2020, 18, e50.

23. Zare-Zardini, H.; Soltaninejad, H.; Ferdosian, F.; Hamidieh, A.A.; Memarpoor-Yazdi, M. Coronavirus Disease 2019 (COVID-19) in Children: Prevalence, Diagnosis, Clinical Symptoms, and Treatment. Int. J. Gen. Med. 2020, 13, 477-482. [CrossRef]

24. De Souza, T.H.; Nadal, J.A.; Nogueira, R.J.N.; Pereira, R.M.; Brandão, M.B. Clinical manifestations of children with COVID-19: A systematic review. Pediatr. Pulmonol. 2020, 55, 1892-1899. [CrossRef]

25. Lechien, J.R.; Chiesa-Estomba, C.M.; De Siati, D.R.; Horoi, M.; Le Bon, S.D.; Rodriguez, A.; Dequanter, D.; Blecic, S.; El Afia, F.; Distinguin, L.; et al. Olfactory and gustatory dysfunctions as a clinical presentation of mild-to-moderate forms of the coronavirus disease (COVID-19): A multicenter European study. Eur. Arch. Oto Rhino Laryngol. 2020, 277, 2251-2261. [CrossRef] [PubMed]

26. Ding, Y.; Yan, H.; Guo, W. Clinical Characteristics of Children With COVID-19: A Meta-Analysis. Front. Pediatr. 2020, 8, 431. [CrossRef]

27. Pal, M.; Berhanu, G.; Desalegn, C.; Kandi, V. Severe Acute Respiratory Syndrome Coronavirus-2 (SARS-CoV-2): An Update. Cureus 2020, 12, e7423. [CrossRef]

28. Hwang, J.; Ryu, H.-S.; Kim, H.A.; Hyun, M.; Lee, J.Y.; Yi, H.-A. Prognostic Factors of COVID-19 Infection in Elderly Patients: A Multicenter Study. J. Clin. Med. 2020, 9, 3932. [CrossRef] [PubMed] 
29. Liu, K.; Chen, Y.; Lin, R.; Han, K. Clinical features of COVID-19 in elderly patients: A comparison with young and middle-aged patients. J. Infect. 2020, 80, e14-e18. [CrossRef]

30. Rui, L.; Sirui, L.; Xuebei, D.; Xujun, Y.; Yanggan, W. Clinical observations in very elderly patients with COVID-19 in Wuhan. Geriatr. Gerontol. Int. 2020, 20, 709-714. [CrossRef] [PubMed]

31. Mahmoudi, S.; Mehdizadeh, M.; Badv, R.S.; Navaeian, A.; Pourakbari, B.; Rostamyan, M.; Ekbatani, M.S.; Eshaghi, H.; Abdolsalehi, M.R.; Alimadadi, H.; et al. The Coronavirus Disease 2019 (COVID-19) in Children: A Study in an Iranian Children's Referral Hospital. Infect. Drug Resist. 2020, 13, 2649-2655. [CrossRef]

32. Mori, H.; Obinata, H.; Murakami, W.; Tatsuya, K.; Sasaki, H.; Miyake, Y.; Taniguchi, Y.; Ota, S.; Yamaga, M.; Suyama, Y.; et al. Comparison of COVID-19 disease between young and elderly patients: Hidden viral shedding of COVID-19. J. Infect. Chemother. 2021, 27, 70-75. [CrossRef]

33. Unicef. Available online: https://www.unicef.org/coronavirus/what-you-need-know-about-delta-variant. (accessed on 21 October 2021).

34. Criado, P.; Abdalla, B.M.Z.; De Assis, I.C.; Mello, C.V.B.D.G.; Caputo, G.C.; Vieira, I.C. Are the cutaneous manifestations during or due to SARS-CoV-2 infection/COVID-19 frequent or not? Revision of possible pathophysiologic mechanisms. Inflamm. Res. 2020, 69, 745-756. [CrossRef]

35. Criado, P.R.; Pagliari, C.; Carneiro, F.R.O.; Quaresma, J.A.S. Lessons from dermatology about inflammatory responses in Covid-19. Rev. Med. Virol. 2020, 30, e2130. [CrossRef]

36. Torres, T.; Puig, L. Managing Cutaneous Immune-Mediated Diseases During the COVID-19 Pandemic. Am. J. Clin. Dermatol. 2020, 21, 307-311. [CrossRef] [PubMed]

37. Miodońska, M.; Bogacz, A.; Mróz, M.; Mućka, S.; Bożek, A. The Effect of SARS-CoV-2 Virus Infection on the Course of Atopic Dermatitis in Patients. Medicina 2021, 57, 521. [CrossRef]

38. Docampo-Simón, A.; Sánchez-Pujol, M.; Juan-Carpena, G.; Palazón-Cabanes, J.; Caso, E.V.; Berbegal, L.; Poveda-Montoyo, I.; Pastor-Tomás, N.; Mataix-Díaz, J.; Terencio-Alemany, C.; et al. Are chilblain-like acral skin lesions really indicative of COVID-19? A prospective study and literature review. J. Eur. Acad. Dermatol. Venereol. 2020, 34, 445-447. [CrossRef] [PubMed]

39. Daneshgaran, G.; Dubin, D.P.; Gould, D.J. Cutaneous Manifestations of COVID-19: An Evidence-Based Review. Am. J. Clin. Dermatol. 2020, 21, 1-13. [CrossRef] [PubMed]

40. Recalcati, S. Cutaneous manifestations in COVID-19: A first perspective. J. Eur. Acad. Dermatol. Venereol. 2020, 34, 212-213. [CrossRef]

41. Freeman, E.E.; McMahon, D.E.; Lipoff, J.B.; Rosenbach, M.; Kovarik, C.; Desai, S.R.; Harp, J.; Takeshita, J.; French, L.E.; Lim, H.W.; et al. The spectrum of COVID-19-associated dermatologic manifestations: An international registry of 716 patients from 31 countries. J. Am. Acad. Dermatol. 2020, 83, 1118-1129. [CrossRef]

42. Estébanez, A.; Pérez-Santiago, L.; Silva, E.; Guillen-Climent, S.; García-Vázquez, A.; Ramón, M.D. Cutaneous manifestations in COVID-19: A new contribution. J. Eur. Acad. Dermatol. Venereol. 2020, 34, 250-251. [CrossRef] [PubMed]

43. Galván Casas, C.; Catala, A.; Carretero Hernández, G.; Rodríguez-Jiménez, P.; Fernández-Nieto, D.; Rodríguez-Villa Lario, A.; Navarro Fernández, I.; Ruiz-Villaverde, R.; Falkenhain-López, D.; Llamas Velasco, M. Classification of the Cutaneous Manifestations of COVID-19: A Rapid Prospective Nationwide Consensus Study in Spain with 375 Cases. Br. J. Dermatol. 2020, 183, 71-77. [CrossRef]

44. Piccolo, V.; Neri, I.; Filippeschi, C.; Oranges, T.; Argenziano, G.; Battarra, V.C.; Berti, S.; Manunza, F.; Fortina, A.B.; Di Lernia, V.; et al. Chilblain-like lesions during COVID-19 epidemic: A preliminary study on 63 patients. J. Eur. Acad. Dermatol. Venereol. 2020, 34, 291-293. [CrossRef]

45. De Masson, A.; Bouaziz, J.D.; Sulimovic, L.; Cassius, C.; Jachiet, M.; Ionescu, M.A.; Rybojad, M.; Bagot, M.; Duong, T.A.; SNDV (French National Union of Dermatologists-Venereologists). Chilblains is a common cutaneous finding during the COVID-19 pandemic: A retrospective nationwide study from France. J. Am. Acad. Dermatol. 2020, 83, 667-670. [CrossRef] [PubMed]

46. Andina, D.; Noguera-Morel, L.; Bascuas-Arribas, M.; Gaitero-Tristán, J.; Alonso-Cadenas, J.A.; Escalada-Pellitero, S.; HernándezMartín, Á.; De La Torre-Espi, M.; Colmenero, I.; Torrelo, A. Chilblains in children in the setting of COVID-19 pandemic. Pediatr. Dermatol. 2020, 37, 406-411. [CrossRef] [PubMed]

47. Singh, C.; Tay, J.; Shoqirat, N. Skin and Mucosal Damage in Patients Diagnosed with COVID-19: A Case Report. J. Wound Ostomy Cont. Nurs. 2020, 47, 435-438. [CrossRef]

48. Chaux-Bodard, A.-G.; Deneuve, S.; Desoutter, A. Oral manifestation of Covid-19 as an inaugural symptom? J. Oral Med. Oral Surg. 2020, 26, 18. [CrossRef]

49. La Rosa, G.R.M.; Libra, M.; De Pasquale, R.; Ferlito, S.; Pedullà, E. Association of Viral Infections with Oral Cavity Lesions: Role of SARS-CoV-2 Infection. Front. Med. 2021, 7, 571214. [CrossRef]

50. Imai, K.; Tanaka, H. SARS-CoV-2 Infection and Significance of Oral Health Management in the Era of "the New Normal with COVID-19. Int. J. Mol. Sci. 2021, 22, 6527. [CrossRef] [PubMed]

51. Dos Santos, J.A.; Normando, A.G.; Da Silva, R.L.C.; De Paula, R.M.; Cembranel, A.C.; Santos-Silva, A.R.; Guerra, E.N.S. Oral mucosal lesions in a COVID-19 patient: New signs or secondary manifestations? Int. J. Infect. Dis. 2020, 97, 326-328. [CrossRef] [PubMed] 
52. Picciani, B.L.S.; Santos, L.R.; Teixeira-Souza, T.; Dick, T.N.A.; Carneiro, S.; Pinto, J.M.N.; Avelleira, J.C.R.; Azulay, D.R.; Luiz, R.R.; Gonzaga, H.F.D.S. Geographic tongue severity index: A new and clinical scoring system. Oral Surg. Oral Med. Oral Pathol. Oral Radiol. 2020, 129, 330-338. [CrossRef]

53. Ansari, R.; Gheitani, M.; Heidari, F.; Heidari, F. Oral cavity lesions as a manifestation of the novel virus (COVID-19). Oral Dis. 2021, 27, 771-772. [CrossRef]

54. Bezerra, T.M.M.; Feitosa, S.G.; Carneiro, D.T.O.; Costa, F.W.G.; Pires, F.R.; Pereira, K.M.A. Oral lesions in COVID-19 infection: Is long-term follow-up important in the affected patients? Oral Dis. 2020, 1, 1-2. [CrossRef]

55. Brandão, T.B.; Gueiros, L.A.; Melo, T.S.; Prado-Ribeiro, A.C.; Nesrallah, A.C.F.A.; Prado, G.V.B.; Santos-Silva, A.R.; Migliorati, C.A. Oral lesions in patients with SARS-CoV-2 infection: Could the oral cavity be a target organ? Oral Surg. Oral Med. Oral Pathol. Oral Radiol. 2021, 131, e45-e51. [CrossRef]

56. Kahraman, F.C.; Çaşkurlu, H. Mucosal involvement in a COVID-19-positive patient: A case report. Dermatol. Ther. 2020, 33, e13797. [CrossRef]

57. Ciccarese, G.; Drago, F.; Boatti, M.; Porro, A.; Muzic, S.I.; Parodi, A. Oral erosions and petechiae during SARS-CoV-2 infection. J. Med. Virol. 2021, 93, 129-132. [CrossRef] [PubMed]

58. Corchuelo, J.; Ulloa, F.C. Oral manifestations in a patient with a history of asymptomatic COVID-19: Case report. Int. J. Infect. Dis. 2020, 100, 154-157. [CrossRef] [PubMed]

59. Tapia, R.O.C.; Labrador, A.J.P.; Guimaraes, D.M.; Valdez, L.H.M. Oral mucosal lesions in patients with SARS-CoV-2 infection. Report of four cases. Are they a true sign of COVID-19 disease? Spéc. Care Dent. 2020, 40, 555-560. [CrossRef]

60. Rodríguez, M.D.; Romera, A.J.; Villarroel, M. Oral manifestations associated with COVID-19. Oral Dis. 2020, epub ahead of print. [CrossRef]

61. Domínguez-Santás, M.; Haya-Martínez, L.; Fernández-Nieto, D.; Jiménez-Cauhé, J.; Suárez-Valle, A.; Díaz-Guimaraens, B. Acute telogen effluvium associated with SARS-CoV-2 infection. Aust. J. Gen. Pract. 2020, 49, 1022-1023. [CrossRef]

62. Glavina, A.; Biočina-Lukenda, D.; Mravak-Stipetić, M.; Markeljević, J. Oral symptoms and lesions in SARS-CoV-2-positive patient. Oral Dis. 2020, epub ahead of print. [CrossRef]

63. Jimenez-Cauhe, J.; Ortega-Quijano, D.; Carretero-Barrio, I.; Suarez-Valle, A.; Saceda-Corralo, D.; Del Real, C.M.; Fernandez-Nieto, D. Erythema multiforme-like eruption in patients with COVID-19 infection: Clinical and histological findings. Clin. Exp. Dermatol. 2020, 45, 892-895. [CrossRef]

64. Kitakawa, D.; Oliveira, F.E.; Neves de Castro, P.; Carvalho, L.F.C.S. Short report-Herpes simplex lesion in the lip semimucosa in a COVID-19 patient. Eur. Rev. Med. Pharm. Sci. 2020, 24, 9151-9153. [CrossRef]

65. Labé, P.; Ly, A.; Sin, C.; Nasser, M.; Chapelon-Fromont, E.; Ben Saïd, P.; Mahé, E. Erythema multiforme and Kawasaki disease associated with COVID-19 infection in children. J. Eur. Acad. Dermatol. Venereol. 2020, 34, 539-541. [CrossRef] [PubMed]

66. Shirato, K.; Imada, Y.; Kawase, M.; Nakagaki, K.; Matsuyama, S.; Taguchi, F. Possible involvement of infection with human coronavirus 229E, but not NL63, in Kawasaki disease. J. Med. Virol. 2014, 86, 2146-2153. [CrossRef]

67. Burns, J.C.; Glodé, M.P. Kawasaki syndrome. Lancet 2004, 364, 533-544. [CrossRef]

68. Martín Carreras-Presas, C.; Amaro Sánchez, J.; López-Sánchez, A.F.; Jané-Salas, E.; Somacarrera Pérez, M.L. Oral vesiculobullous lesions associated with SARS-CoV-2 infection. Oral Dis. 2020, 27, 710-712. [CrossRef] [PubMed]

69. Nuno-Gonzalez, A.; Martin-Carrillo, P.; Magaletsky, K.; Rios, M.M.; Mañas, C.H.; Almazan, J.A.; Casasola, G.G.; Castro, E.P.; Arenas, A.G.; Ibarguren, A.M.; et al. Prevalence of mucocutaneous manifestations in 666 patients with COVID-19 in a field hospital in Spain: Oral and palmoplantar findings. Br. J. Dermatol. 2021, 184, 184-185. [CrossRef]

70. Patel, J.; Woolley, J. Necrotizing periodontal disease: Oral manifestation of COVID-19. Oral Dis. 2021, 27, 768-769. [CrossRef] [PubMed]

71. Putra, B.E.; Adiarto, S.; Dewayanti, S.R.; Juzar, D.A. Viral exanthem with "Spins and needles sensation" on extremities of a COVID-19 patient: A self-reported case from an Indonesian medical frontliner. Int. J. Infect. Dis. 2020, 96, 355-358. [CrossRef] [PubMed]

72. Riad, A.; Kassem, I.; Issa, J.; Badrah, M.; Klugar, M. Angular cheilitis of COVID-19 patients: A case-series and literature review. Oral Dis. 2020. [CrossRef] [PubMed]

73. Riad, A.; Kassem, I.; Hockova, B.; Badrah, M.; Klugar, M. Tongue Ulcers Associated with SARS-COV-2 Infection: A case-series. Oral Dis. 2020. [CrossRef] [PubMed]

74. Sakaida, T.; Tanimoto, I.; Matsubara, A.; Nakamura, M.; Morita, A. Unique skin manifestations of COVID-19: Is drug eruption specific to COVID-19? J. Dermatol. Sci. 2020, 99, 62-64. [CrossRef]

75. Soares, C.; Carvalho, R.; Carvalho, M.; Almeida, O. Letter to Editor: Oral lesions in a patient with Covid-19. Med. Oral Patol. Oral Y Cir. Bucal 2020, 25, e563-e564. [CrossRef]

76. Pedersen, S.F.; Ho, Y.-C. SARS-CoV-2: A storm is raging. J. Clin. Investig. 2020, 130, 2202-2205. [CrossRef]

77. Cekici, A.; Kantarci, A.; Hasturk, H.; Van Dyke, T.E. Inflammatory and immune pathways in the pathogenesis of periodontal disease. Periodontol. 2000 2014, 64, 57-80. [CrossRef]

78. Coke, C.; Davison, B.; Fields, N.; Fletcher, J.; Rollings, J.; Roberson, L.; Challagundla, K.; Sampath, C.; Cade, J.; FarmerDixon, C.; et al. SARS-CoV-2 Infection and Oral Health: Therapeutic Opportunities and Challenges. J. Clin. Med. 2021, 10, 156. [CrossRef] [PubMed] 
79. Molayem, S.; Pontes, C.C. The Mouth-COVID Connection: Il-6 Levels in Periodontal Disease-Potential Role in COVID-19-Related Respiratory Complications. J. Calif. Dent. Assoc. 2020, 40, 68-80.

80. Daniel, R.; Gokulanathan, S.; Shanmugasundaram, N.; Lakshmigandhan, M.; Kavin, T. Diabetes and periodontal disease. J. Pharm. Bioallied Sci. 2012, 4, S280. [CrossRef] [PubMed]

81. Preshaw, P.M.; Alba, A.L.; Herrera, D.; Jepsen, S.; Konstantinidis, A.; Makrilakis, K.; Taylor, R. Periodontitis and diabetes: A two-way relationship. Diabetologia 2011, 55, 21-31. [CrossRef] [PubMed]

82. Paul, O.; Arora, P.; Mayer, M.; Chatterjee, S. Inflammation in Periodontal Disease: Possible Link to Vascular Disease. Front. Physiol. 2021, 11, 609614. [CrossRef]

83. Pitones-Rubio, V.; Chávez-Cortez, E.; Hurtado-Camarena, A.; González-Rascón, A.; Serafín-Higuera, N. Is periodontal disease a risk factor for severe COVID-19 illness? Med. Hypotheses 2020, 144, 109969. [CrossRef] [PubMed]

84. Marouf, N.; Cai, W.; Said, K.N.; Daas, H.; Diab, H.; Chinta, V.R.; Hssain, A.A.; Nicolau, B.; Sanz, M.; Tamimi, F. Association between periodontitis and severity of COVID-19 infection: A case-control study. J. Clin. Periodontol. 2021, 48, 483-491. [CrossRef] [PubMed]

85. Takahashi, Y.; Watanabe, N.; Kamio, N.; Kobayashi, R.; Iinuma, T.; Imai, K. Aspiration of periodontopathic bacteria due to poor oral hygiene potentially contributes to the aggravation of COVID-19. J. Oral Sci. 2021, 63, 1-3. [CrossRef] [PubMed]

86. Brian, Z.; Weintraub, J.A. Oral Health and COVID-19: Increasing the Need for Prevention and Access. Prev. Chronic Dis. 2020, 17, E82. [CrossRef] [PubMed]

87. Sampson, V.; Kamona, N.; Sampson, A. Could there be a link between oral hygiene and the severity of SARS-CoV-2 infections? Br. Dent. J. 2020, 228, 971-975. [CrossRef]

88. Botros, N.; Iyer, P.; Ojcius, D.M. Is there an association between oral health and severity of COVID-19 complications? Biomed. J. 2020, 43, 325-327. [CrossRef]

89. Karayanni, H.; Dror, A.A.; Oren, D.; Sela, E.; Granot, I.; Srouji, S. Exacerbation of chronic myofascial pain during COVID-19. Adv. Oral Maxillofac. Surg. 2021, 1, 100019. [CrossRef]

90. Consolo, U.; Bellini, P.; Bencivenni, D.; Iani, C.; Checchi, V. Epidemiological Aspects and Psychological Reactions to COVID-19 of Dental Practitioners in the Northern Italy Districts of Modena and Reggio Emilia. Int. J. Environ. Res. Public Health 2020, 17, 3459. [CrossRef]

91. Saccomanno, S.; Bernabei, M.; Scoppa, F.; Pirino, A.; Mastrapasqua, R.; Visco, M.A. Coronavirus Lockdown as a Major Life Stressor: Does It Affect TMD Symptoms? Int. J. Environ. Res. Public Health 2020, 17, 8907. [CrossRef]

92. Rokaya, D.; Koontongkaew, S. Can Coronavirus Disease-19 Lead to Temporomandibular Joint Disease? Open Access Maced. J. Med. Sci. 2020, 8, 142-143. [CrossRef]

93. Almeida-Leite, C.M.; Stuginski-Barbosa, J.; Conti, P.C.R. How psychosocial and economic impacts of COVID-19 pandemic can interfere on bruxism and temporomandibular disorders? J. Appl. Oral Sci. 2020, 28, e20200263. [CrossRef]

94. Di Giacomo, P.; Serritella, E.; Imondi, F.; Di Paolo, C. Psychological impact of COVID-19 pandemic on TMD subjects. Eur. Rev. Med. Pharmacol. Sci. 2021, 25, 4616-4626. [CrossRef]

95. Di Blasi, M.; Gullo, S.; Mancinelli, E.; Freda, M.F.; Esposito, G.; Gelo, O.C.G.; Lagetto, G.; Giordano, C.; Mazzeschi, C.; Pazzagli, C.; et al. Psychological distress associated with the COVID-19 lockdown: A two-wave network analysis. J. Affect. Disord. 2021, 284, 18-26. [CrossRef]

96. Rocha, J.R.; Neves, M.J.; Pinheiro, M.R.R.; Feitosa, M.; Áurea, L.; Casanovas, R.C.; Lima, D.M. Alterações psicológicas durante a pandemia por COVID-19 e sua relação com bruxismo e DTM. Res. Soc. Dev. 2021, 10, 48710615887. [CrossRef]

97. Emodi-Perlman, A.; Eli, I.; Smardz, J.; Uziel, N.; Wieckiewicz, G.; Gilon, E.; Grychowska, N.; Wieckiewicz, M. Temporomandibular Disorders and Bruxism Outbreak as a Possible Factor of Orofacial Pain Worsening during the COVID-19 Pandemic-Concomitant Research in Two Countries. J. Clin. Med. 2020, 9, 3250. [CrossRef]

98. Asquini, G.; Bianchi, A.E.; Borromeo, G.; Locatelli, M.; Falla, D. The impact of Covid-19-related distress on general health, oral behaviour, psychosocial features, disability and pain intensity in a cohort of Italian patients with temporomandibular disorders. PLoS ONE 2021, 16, e0245999. [CrossRef]

99. Alona, E.-P.; Ilana, E. One year into the COVID-19 pandemic-temporomandibular disorders and bruxism: What we have learned and what we can do to improve our manner of treatment. Dent. Med. Probl. 2021, 58, 215-218. [CrossRef] [PubMed]

100. De Boni, R.B.; Balanzá-Martínez, V.; Mota, J.C.; Cardoso, T.D.A.; Ballester, P.; Atienza-Carbonell, B.; Bastos, I.F.; Kapczinski, F. Depression, Anxiety, and Lifestyle Among Essential Workers: A Web Survey from Brazil and Spain During the COVID-19 Pandemic. J. Med. Internet Res. 2020, 22, e22835. [CrossRef]

101. Peixoto, K.O.; de Resende, C.M.B.M.; de Almeida, E.O.; Almeida-Leite, C.M.; Conti, P.C.R.; Barbosa, G.A.S.; Barbosa, J.S. Association of sleep quality and psychological aspects with reports of bruxism and TMD in Brazilian dentists during the COVID-19 pandemic. J. Appl. Oral Sci. 2021, 29, e20201089. [CrossRef] [PubMed]

102. Gaş, S.; Özsoy, H.E.; Aydın, K.C. The association between sleep quality, depression, anxiety and stress levels, and temporomandibular joint disorders among Turkish dental students during the COVID-19 pandemic. CRANIO 2021, 5, 1-6. [CrossRef] [PubMed]

103. De Medeiros, R.A.; Vieira, D.L.; Da Silva, E.V.F.; Rezende, L.V.M.D.L.; Dos Santos, R.W.; Tabata, L.F. Prevalence of symptoms of temporomandibular disorders, oral behaviors, anxiety, and depression in Dentistry students during the period of social isolation due to COVID-19. J. Appl. Oral Sci. 2020, 28, e20200445. [CrossRef] [PubMed] 
104. Mahdi, S.; Ahmed, Z.; Allana, R.; Peretti, A.; Amenta, F.; Bijle, M.N.; Seow, L.; Daood, U. Pivoting Dental Practice Management during the COVID-19 Pandemic-A Systematic Review. Medicina 2020, 56, 644. [CrossRef] [PubMed]

105. Ather, A.; Patel, B.; Ruparel, N.B.; Diogenes, A.; Hargreaves, K.M. Coronavirus Disease 19 (COVID-19): Implications for Clinical Dental Care. J. Endod. 2020, 46, 584-595. [CrossRef] [PubMed]

106. Ahmed, M.; Jouhar, R. Dissemination of Aerosol and Splatter in Clinical Environment during Cavity Preparation: An In Vitro Study. Int. J. Environ. Res. Public Health 2021, 18, 3773. [CrossRef] [PubMed]

107. Persoon, I.; Stankiewicz, N.; Smith, A.; de Soet, H.; Volgenant, C. A review of respiratory protection measures recommended in Europe for dental procedures during the COVID-19 pandemic. J. Hosp. Infect. 2020, 106, 330-331. [CrossRef] [PubMed]

108. Soltani, P.; Baghaei, K.; Tafti, K.T.; Spagnuolo, G. Science Mapping Analysis of COVID-19 Articles Published in Dental Journals. Int. J. Environ. Res. Public Health 2021, 18, 2110. [CrossRef]

109. Peng, X.; Xu, X.; Li, Y.; Cheng, L.; Zhou, X.; Ren, B. Transmission routes of 2019-nCoV and controls in dental practice. Int. J. Oral Sci. 2020, 12, 9. [CrossRef]

110. Shi, A.H.; Guo, W.; Chng, C.K.; Chan, B.H. Precautions When Providing Dental Care During Coronavirus Disease 2019 (COVID-19) Pandemic. Ann. Acad. Med. Singap. 2020, 49, 312-319. [CrossRef]

111. Ghai, S. Facial Trauma Management During the COVID-19 Era: A Primer for Surgeons. Curr. Med. Res. Pract. 2020, 10, 169-173. [CrossRef]

112. Sinjari, B.; Rexhepi, I.; Santilli, M.; D'addazio, G.; Chiacchiaretta, P.; Di Carlo, P.; Caputi, S. The Impact of COVID-19 Related Lockdown on Dental Practice in Central Italy-Outcomes of A Survey. Int. J. Environ. Res. Public Health 2020, 17, 5780. [CrossRef]

113. Tysiąc-Miśta, M.; Dziedzic, A. The Attitudes and Professional Approaches of Dental Practitioners during the COVID-19 Outbreak in Poland: A Cross-Sectional Survey. Int. J. Environ. Res. Public Health 2020, 17, 4703. [CrossRef]

114. Al-Omiri, M.K.; Lynch, E.; Patil, S.; Al-Shayyab, M.H.; Al Nazeh, A.A.; Alraheam, A.I.; Malkawi, A.Z.; Alomiri, A.K.; Alzoubi, A.I. COVID-19 and Dentistry: An Updated Overview of Dental Perspectives and a Recommended Protocol for Dental Care and Emergency Dental Treatment. J. Contemp. Dent. Pract. 2021, 22, 572-586. [CrossRef]

115. Tonkaboni, A.; Amirzade-Iranaq, M.H.; Ziaei, H.; Ather, A. Impact of COVID-19 on Dentistry. Adv. Exp. Med. Biol. 2021, 1318, 623-636. [CrossRef]

116. Alharbi, A.; Alharbi, S.; Alqaidi, S. Guidelines for dental care provision during the COVID-19 pandemic. Saudi Dent. J. 2020, 32, 181-186. [CrossRef]

117. Izzetti, R.; Nisi, M.; Gabriele, M.; Graziani, F. COVID-19 Transmission in Dental Practice: Brief Review of Preventive Measures in Italy. J. Dent. Res. 2020, 99, 1030-1038. [CrossRef] [PubMed]

118. Lo Giudice, R. The Severe Acute Respiratory Syndrome Coronavirus-2 (SARS CoV-2) in Dentistry. Management of Biological Risk in Dental Practice. Int. J. Environ. Res. Public Health 2020, 17, 3067. [CrossRef] [PubMed]

119. Sarapultseva, M.; Hu, D.; Sarapultsev, A. SARS-CoV-2 Seropositivity among Dental Staff and the Role of Aspirating Systems. JDR Clin. Transl. Res. 2021, 6, 132-138. [CrossRef] [PubMed]

120. Amato, A.; Caggiano, M.; Amato, M.; Moccia, G.; Capunzo, M.; De Caro, F. Infection Control in Dental Practice During the COVID-19 Pandemic. Int. J. Environ. Res. Public Health 2020, 17, 4769. [CrossRef]

121. Van Doremalen, N.; Bushmaker, T.; Morris, D.H.; Holbrook, M.G.; Gamble, A.; Williamson, B.N.; Tamin, A.; Harcourt, J.L.; Thornburg, N.J.; Gerber, S.I.; et al. Aerosol and Surface Stability of SARS-CoV-2 as Compared with SARS-CoV-1. N. Engl. J. Med. 2020, 382, 1564-1567. [CrossRef] [PubMed]

122. Kampf, G.; Todt, D.; Pfaender, S.; Steinmann, E. Persistence of coronaviruses on inanimate surfaces and their inactivation with biocidal agents. J. Hosp. Infect. 2020, 104, 246-251. [CrossRef]

123. Little, R.; Howell, J.; Nixon, P. COVID-19 and beyond: Implications for dental radiography. Br. Dent. J. 2020, $229,105-109$. [CrossRef]

124. Dziedzic, A.; Wojtyczka, R. The impact of coronavirus infectious disease 19 (COVID-19) on oral health. Oral Dis. 2021, 27, 703-706. [CrossRef] [PubMed]

125. Samaranayake, L.; Fakhruddin, K.S.; Bandara, N. Oral Manifestations of Coronavirus Disease 2019 (COVID-19): An Overview. Dent. Updat. 2021, 48, 418-422. [CrossRef]

126. Sinjari, B.; D'Ardes, D.; Santilli, M.; Rexhepi, I.; D'Addazio, G.; Di Carlo, P.; Chiacchiaretta, P.; Caputi, S.; Cipollone, F. SARS-CoV-2 and Oral Manifestation: An Observational, Human Study. J. Clin. Med. 2020, 9, 3218. [CrossRef]

127. Godinho, G.V.; Paz, A.L.L.M.; Gomes, E.P.A.D.A.; Garcia, C.L.; Volpato, L.E.R. Extensive hard palate hyperpigmentation associated with chloroquine use. Br. J. Clin. Pharmacol. 2020, 86, 2325-2327. [CrossRef] [PubMed] 